\section{KOMPARATIF TEKNIK DAN EKSPRESI DALAM SENI KRIYA}

\section{Wayan Suardana \\ FSRD ISI Denpasar}

\section{Abstract}

In modern system fine arts discourse these days, expression and technique region is always questioned to assign value whether/what the masterpiece can category as swan song or not. Expression always made by ivorytower in creation of swan song of technique and always the attention cannot and considered to be skilled as supporter in course of the creation. Expression is even also comprehended and careful shallow/ superficially where swan song which is not borne with emotional emotion it is not the expressive masterpiece endless. Understanding confusion bear all discourse of confused which to isolate in the end swan song which adiluhung placedly at region of swan song of under because assumed less be expressive. Regionas discourse problem of expression and technique befall art kriya so that on the way nya artis tic [of] kriya have and technique befall an krya so that on the way nya attis tic [of] kriya have the artic once where art craft which adiluhung category as ant of second class of because its birth is assumed only need mere crafmanshif and without carrying expression. Discourse mistake and have enter of at system discourse of fine arts by komfrehensif require to be straightened, so that domicile art become is equal to energy and material express different.

Key word: kriya, crafmanshif, adiluhung

\section{A. Pendahuluan}

Kriya adalah salah satu cabang seni rupa yang kelahirannya bersamaan dengan manusia mulai berbudaya. Dengan akal budi dan ketrampilan tangan manusia mereka menciptakan berbagai perabotan dengan memanfaatkan lingkungan alam yang ada dan digunakan untuk memenuhi kebutuhan hidupnya sehari hari, baik yang berkaitan dengan kebutuhan jasmani maupun rohani. Segala aktivitas hidup selalu memerlukan beragam sarana dan prasarana, di antaranya membutuhkan kehadiran karya kriya yang khas. Berbagai bentuk perabotan yang merupakan karya kriya diciptakan oleh masyarakat yang dikerjakan secara turuntemurun dan disesuaikan dengan kebutuhan hidup pada jamannya. Sebagai sebuah produk yang selalu dibutuhkan masyarakat pendukungnya, kriya selalu mengalami perkembangan tentunya dibarengi dengan berbagai perubabahan dan penyempurnaan, baik yang berkaitan dengan bentuk, ragam, teknik dan material bahkan wacana yang menyertai di dalamnya (Gustami, 2003:14)

Kurun waktu yang panjang dengan melewati berbagai proses, bukan waktu yang cukup untuk menempatkan kriya pada wilayah seni rupa yang kuat dan

Imaji, Vol.4, No.1, Februari $2006: 32$ - 45 ajeg, bahkan kedudukan kriya semakin goyah dan selalu menjadi pergunjingan bagi semua pihak yang berkompeten dalam bidang ini. Pergunjingan tidak terbatas pada masalah etimologi dan terminologi kriya saja, tetapi sudah meluwas pada wilayah yang lainnya baik yang berkaitan dengan bentuk, wujud karya, proses penciptaan, kandungan nilai yang ada di dalamnya, yang pada akhirnya berimplikasi pada kedudukan kriya dengan seni-seni yang lainnya. Sungguh sangat sayang sekali dimana kriya yang sudah berumur panjang dan merupakan cikal bakal dari seni rupa lainnya selalu terombang-ambing dengan istilahnya sendiri. Bahkan yang sangat menyedihkan di mana kriya dianggap sebuah karya seni kelas dua atau kelas bawah bahkan pernah dikatakan bukan karya seni karena dianggap kurang ekspresif.

Perlu disadari bahwa permasalahan selalu muncul pada kriya dengan timbulnya berbagai persepsi yang beraneka ragam karena lingkup wilayah kriya terlalu luas baik yang berkaitan dengan material, teknik yang digunakan serta produk sebagai hasil ciptaannya. Perkembangan seni rupa secara global yang dibarengi dengan merebaknya tataran wacana dalam setiap ajang perhelatannya menjadikan kriya semakin menjauh dengan seni rupa lainnya karena frekwensi pemunculan kriya sangat minim yang pada akhirnya dianggap sebagai seni yang kurang kreatif.

Permasalahan yang selama ini selalu menjadi pergunjingan pada kriya baik pada wilayah wacana maupun hasil ciptaannya adalah berkutatnya dikotomi yang sangat kuat dan tajam pada wilayah teknik dan ekspresi pada proses penciptaan karya seni. Penciptaan karya kriya selalu dipertanyakan keberadaannya, apakah kriya berada pada wilayah seni murni, disain atau berkutat pada seni kerajinan. Bila dipahami secara mendasar teknik dan ekspresi sangat mustahil bila tidak terdapat pada setiap penciptaan karya seni. Tanpa adanya teknik dan ekspresi karya seni tidak akan pernah tercipta. Yang menjadi pertanyaan adalah kenapa dua wilayah ini dibuat dikotomi yang tajam dan kriya selalu dijadikan obyek permasalahan. Dalam tulisan ini tidak akan memaparkan secara diskriptif tentang berbagai teknik yang terdapat dalam proses penciptaan kriya, namun akan mencoba membahas secara rinci peran dan kedudukan teknik dan ekspresi dalam proses penciptaan karya kriya dari awal kelahirannya sampai pada penciptaan kriya dewasa ini. Permasalahan ini diangkat untuk memberikan pemahaman secara umum pada masyarakat bahwa proses penciptaan karya kriya dimana teknik dan ekspresi selalu beriringan, dan yang membedakan adalah kapasitas yang terkandung di dalamnya. Untuk tidak menimbulkan kesalahan persepsi yang semakin rancu sebaiknya akan dibahas secara substansial tentang teknik dan ekspresi tersebut. 


\section{B. Teknik dan Ekspresi}

Yunani adalah sebuah negara yang dipandang sebagai sumber kebudayaan Eropa, walaupun sejak awal sejarahnya sudah mengenal filsafat dan juga filsafa seni, ternyata juga tidak memiliki kata yang dapat disejajarkan dengan pengertian kita sekarang tentang seni. Istilah yang paling dekat dengan istilah itu ialah "Tekchne" yang sekarang kita kenal memiliki hubungan langsung dengan perkataan "Teknik". Menurut Aristoteles, techne (sebut sajalah seni) adalah kemampuan untuk membuat atau mengerjakan sesuatu disertai dengan pengertian yang betul tentang prinsip-prinsipnya (Soedarso, 1990:9). Kemampuan menciptakan sesuatu dengan menggunakan teknik tertentu yang dilandasi dengan pemikiran yang kuat dan dapat memberikan argumentasi secara mendasar pada hasil ciptaan tersebut, maka ciptaan tersebut merupakan suatu karya seni. Teknik adalah seni dalam menciptakan sesuatu dengan berbagai pertimbangan yang matang.

Terkait dengan masalah teknik, Guntur (2001:84) menguraikan bahwa teknik penciptaan merupakan wahana dalam mengekspresikan ide, gagasan, pikiran bagi seniman. Oleh karena itu kemampuan teknik merupakan kekuatan dasar bagi seniman karena teknik yang baik akan menjadikan karya seni yang baik pula. Ide dan gagasan yang baik tanpa didukung oleh kemampuan dan kesempurnaan teknik niscaya akan mendapatkan hasil yang sempurna.

Teknik, betapapun keberadaannya tetap mutlak dipersyaratkan dalam proses penciptaan karya seni, persoalannya barangkali berbeda pada tingkat itensitas kemampuan yang dimiliki masing-masing senimannya. Di satu sisi ia berkesan spontan seolah-olah mengalir deras karena mengikuti akselerasi emosi yang menuntut segera tercurahkan, di sisi lain ia hadir dalam perhitungan dan pertimbangan yang matang pada suatu karya (Guntur, 2001:83). Kedudukan teknik pada suatu proses penciptaan akan menjadi ekor dari ide, gagasan, imajinasi, dan dengan spontan akan muntah pada suatu media, namun sebaliknya teknik juga akan menjadi garda depan sebagai pengarah pada luapan emosi tersebut.

Thomas Munro menyatakan bahwa tiap-tiap fase dalam produksi seni mengembangkan ketrampilan atau tekniknya sendiri-sendiri. Teknik artistik dapat diklasifikasikan dan digambarkan ke dalam berbagai cara, dan hal yang terkait dengan persoalan fisik akan bertalian dengan medium, materi, dan instrumen. Di samping itu teknik dapat juga digambarkan menurut hasil dalam berbagai karakteristik produk, serta dalam konteks yang lebih luas teknik juga dapat digambarkan sebagai proses (Munro, 1969:315).

Ekspresi merupakan suatu hal yang harus ada dalam proses penciptaan karya seni. Ekspresi menurut Stolnits adalah proses kresi artistik yang membimbing kearah karya di satu sisi dan menunjuk sifat intrinsik karya itu sendiri di sisi lain. Pada stratum pertama, ekspresi dicapai melalui pengamatan terhadap obyek yang menginkubasi pada diri seniman, yang selanjutnya gagasan, pikiran serta emosi itu diformulasikan kedalam bentuk tertentu (Stolnitz, 1960:128). Menurut Plato yang disitir oleh Thomas Munro, kreasi artistik secara longgar merupakan hasil kegilaan atau inspirasi yang hebat dan seniman merupakan seseorang yang memiliki kemampuan luar biasa atas inspirasi yang dicapainya (Munro, 1969:326)

Ekspresi adalah suatu perkataan yang amat dualistik artinya: Ekspresi dipergunakan untuk menyebutkan reaksi-reaksi emosional yang lansung; namun bentuk-bentuk yang dicapai melalui aturan-aturan yang ketatpun merupakan suatu cara berekspresi. Sekalipun bentuk itu juga bisa dianalisis menurut istilah intelektual namun ia merupakan intuitif. Saluran emosional seharusnya menjadi peminpin bagi seorang artis dan bukan saluran intelektual terutama apabila kita menentukan seni sebagai the will to form (Read, 2000:5). Ekspresi bukan semata sebagai luapan emosi yang secara spontan akan dimuntahkan pada suatu materi, namun dengan penggorganisasian berbagai bentuk, bidang, ruang juga merupakan sarana dalam berekspresi. Ekspresi akan banyak dikendalikan intelek yang dalam seni biasanya akan berkaitan erat dengan komposisi, proporsi, irama, fokus, bahkan teknikpun kemungkinan besar juga merupakan alat kendali dalam ekspresi. Yrjo Hirn (1870-1952), Profesor sosiologi dari Universitas Holsingfors di Finlandia, dengan keyakinannya bahwa ekspresi emosional adalah esensi dari semua seni. Secara fisiologis awal mula dari aktivitas kesenian adalah usaha manusia untuk membebaskan diri dari tekanan emosionalnya. Proses penciptaan seni memerlukan kontrol kritis dan karena itu nafsu-nafsu yang kacau harus dikendalikan oleh intelek. Ekspresi yang emosional itu diatur kelahirannya oleh bentuk, ukuran, harmoni, estetik, dan sebagainya (Soedarso, 2003:4-5).

Ekspresi menurut Veron, adalah suatu curahan ke luar dari seseorang yang hasilnya bukan ditangkapnya apa yang dicurahkan itu kepada orang lain, melainkan adalah menjadi leganya orang yang berekspresi karena unek-uneknya sudah tersalur keluar, isi dan gejolak hatinya sudah tidak mengganjal lagi.

Mencermati beberapa pendapat di atas yang berkaitan dengan ekspresi secara garis besar ada dua makna yang terkandung dalam ekspresi tersebut. Yang satu sangat ektrim di mana ekpresi merupakan luapan emosional yang tercurah secara total tanpa tendeng aling apa-apa. Yang kedua lebih rasional di mana ekspresi merupakan luapan emosional yang dikendalikan oleh intelek sehingga berbagai pertimbangan harus diperhatikan sebelum seseorang berekspresi dalam menciptakan karya seninya.

Teknik dan ekpresi adalah dwi tunggal yang harus melandasi proses 
penciptaan karya seni. Ekspresi mewadahi ide, gagasan emosional, intuisi, imajinasi, sedangkan teknik akan mewadahi material, gaya, dan elemen estetis lainnya. Ekspresi sebagai aktivitas yang bersifat emosional, dan teknik penciptaan sebagai aktivitas intelektual.

Dalam penciptaan sebuah karya seni ekspresi hadir melalui serangkaian proses baik yang bersifat spontan maupun melalui berbagai pertimbangan dan pemikiran intelektual. Ekspresi merupakan perwujudan gagasan, pikiran, imajinasi maupun emosi subyektif seniman. Dalam kenyataan ekspresi spontan bukan tanpa kendala manakala seniman tidak memiliki ketrampilan tertentu. Dalam konteks seperti itu seorang seniman dituntut untuk menguasai teknik sebagai persyarat untuk mengungkapkan gagasannya (Guntur, 2001:80).

\section{Kriya dan Seni}

Dikotomi yang kuat dan tajam pada teknik dan ekspresi berimplikasi kepada kedudukan antara Kriya dan Seni. Agungnya nilai ekspresi sebagai menara gading dalam proses penciptaan karya seni menjadikan kriya terdepak dari percaturan seni rupa. Pada saat ekspresi spontan, emosi, improfisasi, sedang merajai kesenian dunia dengan manifestasinya dalam abstrak ekspresionisme yang tersebar luas, seni ukir(kriya) tersisih dari seni rupa, bahkan banyak kali diharamkan masuk ke dalam ruang lingkup kesenian tersebut dengan tuduhan ia bukan karya seni, dan dianggap sebagai sebuah ketangkasan karya tukang belaka (Soedarso, 2003:47). Sesuatu yang sangat sayang sekali sebuah karya yang adiluhung terdepak dari percaturan seni rupa hanya dengan memandang sebelah mata bahwa kriya sebagai karya tukang tanpa mengusung ekspresi didalamnya.

Kalau kita kembali menengok ke belakang sesungguhnya semua sen adalah seni kriya, tetapi dalam perkembangan selanjutnya seni-seni yang lebih ekspresif, yang murni estetik dan kurang mementingkan kekriyaan memisahkan diri (Soedarso, 2003:15). Seni kriya adalah akar seni rupa Indonesia. Berka timbulnya diferensiasi, difersifikasi, dan spesialisasi, masing-masing bidang yang semula terwadahi dalam bidang seni kriya kemudian memisahkan diri dan secara otonum berkembang sehingga berasil menjadi disiplin seni tersendiri (Gustami, 2002:9).

Kedudukan teknik dan ekspresi semakin menguat manakala sen diklasifikasikan menjadi dua yaitu seni murni (fine art) dan seni terapan (applaed $a r t$ ). Seni murni lebih identik dengan seni yang mengusung ekspresi dengan penuh kebebasan dan seni terapan lebih identik dengan seni yang lebih mengandalkan kekuatan teknik disamping pertimbangan-pertimbangan lainnya. Seni murni adalah seni yang subyektif dan seni terapan adalah seni obyektif. Demikian juga predikat dari masing-masing pelaku seni disini berbeda. Pelaku seni murni disebut dengan seniman (artist) dan pelaku seni terap disebut dengan kriyawan

Imaji, Vol.4, No.1, Februari $2006: 32$ - 45 (craftsmen).

Keterbatasan pemahaman definisi seni rupa yang sejak awal ditekankan pada usaha membedakan fine art dan applaed art, dimana nominasi tetap berada pada seni murni yang hanya terwujud pada seni lukis dan patung saja. Sedangkan applaed art dianggap seni "kelas dua" (Djatiprambudi, 2004:2). Pemahaman yang sempit itu, sebagian besar perupa itu secara naip percaya bahwa media ekspresi seni rupa adalah seni lukis dan seni patung. Media seni lain seperti grafis dan kriya adalah media seni yang minim ekspresi, sehingga sering terlewatkan dalam wacana seni rupa yang sedang berkecamuk dewasa ini.

Ditinjau dari ide penciptaan, awalnya secara garis besar antara kriya dan seni memang sedikit berbeda. Kriya selalu dibuat dengan tujuan pragmatis, membuat benda yang mempunyai manfaat praktis dan fsikologis tertentu. Seni diciptakan karena keinginan mengekpresikan ide dan tujuan yang idial non praktis, transenden, dan subyektif. Seni timbul dari pengalaman subyektif manusia. Pada kriya craftmanship adalah segala-galanya (Gustami, 2002:17).

Wacana antara kriya dan seni di dunia baratpun masih menjadi perdebatan pada tataran proses maupun produk yang dihasilkan. Jika art adalah pemikiran "idea" dan "konsep", maka craf adalah "membuat sesuatu". Art merefleksikan daya imajinasi yang kreatif, sedangkan craf adalah "ketrampilan" membuat sesuatu (Irianto, 2005:29). Perbedaan antara seni sebagai sebuah ide, konsep yang diekspresikan pada sebuah penciptaan dengan kriya sebagai suatu ketrampilan membuat sesuatu masih tetap kokoh bahkan ketrampilan tidak menjadi keharusan dalam karya seni karena karya seni merupakan hasil pemikiran dan konsep.

Beberapa pendapat diatas secara garis besar masih memberikan pembatasan yang kuat dan tajam pada wilayah teknik dan ekspresi yang berimplikasi pada pembatasan ruang antara kriya dan seni. Berbagai pernyataan di atas tentunya tidak dapat dipahami secara mutlak karena kalau ditelaah secara mendalam pemisahan itu sebenarnya tanpa batas tembok yang kokoh sebagai akibat dari segala sesuatunya akan mengalami perkembangan dengan kemungkinan besar akan saling bersentuhan dan saling mempengaruhi. Teknik dan ekspresi bukannya dua wilayah yang harus dipisahkan dan dipertentangkan, namun harus diselaraskan tentunya dengan aksentuasi yang berbeda. Ekspresi bukanlah monopoli salah satu aliran maupun cabang seni, ia hadir dalam berbagai manifestasi dengan beragam media ungkapnya. Demikian juga teknik akan selalu menyertai kehadiran karya seni. Namun demikian dalam tataran wacana dan apresiasi seni, teknik selalu terabaikan, pada hal banyak karya seni yang sering kali memperoleh apresiasi konprehensipnya tanpa meninggalkan teknik, karena betapapun masalah teknik selalu berkaitan dengan aspek kebentukan karya (Guntur, 2001:85).

Komparatif Teknik dan Ekspresi Dalam Seni Kriya (I Wayan Suardana) 
Sungguh sangat diskriminatif apabila masih memperuncing wilayah kriya dan seni hanya lantaran dikotomi antara teknik dan ekspresi, apalagi menempatkan kriya bukan sebagai karya seni lantaran dalam kelahirannya hanya menekankan kekriyaan. Predikat ini sulit diterima pada wilayah kriya manapun. Sepertinya suatu yang sangat keliru apabila kita selalu memaksakan wacana yang datang dari luar dengan mengobok-ngobok kemapanan apa yang kita telah miliki sebagai warisan budaya. Sebelum kita membedah apa yang kita miliki seharusnya kita harus mencocokan intrumen yang akan kita gunakan sehingga apa yang kita harapkan akan tercapai. Adalah merupakan tugas para kritisi untuk meluruskan dan memberikan apresiasi yang benar sehingga tidak menimbulkan kecemburuan pada wilayah yang dirugikan.

\section{Teknik dan Ekspresi dalam Seni Kriya}

Kalau diamati secara mendasar permasalahan antara teknik dan ekspresi dalam seni kriya adalah "kekuatan" atau "aksentuasi" yang terkandung di dalamnya pada proses penciptaannya serta sasaran produk yang dihasilkannya. Ekspresi yang dimaksud di sini adalah ekspresi yang dikendalikan oleh intelek dan bukan ekspresi yang meluap-luap. Untuk dapat mengetahuai secara mendalam kekuatan tersebut, pembahasannya harus diawali dari perjalanan seni kriya itu sendiri baik secara historis maupun akademis. Dari perjalanan ini secara tidak langsung kekuatan kandungan teknik dan ekspresi dalam setiap proses penciptaan akan terwujud dengan jelas.

Garis lintang kualitas antara teknik dan ekspresi pada setiap kelahiran dan sasaran karya kriya sebenarnya sudah sangat jelas, namun dalam proses penciptaan tersebut mereka sama sekali tidak mempermasalahkan apa yang mereka kerjakan. Dalam tahap yang paling sederhana sesuai dengan pola kehidupan manusia pada waktu itu proses penciptaan perabotan sudah sanga berbeda. Bagaimana mereka membuat prabotan rumah tangga untuk keperluan hidup sehari-hari sangat berbeda dengan proses penciptaan perabotan untuk peralatan upacara misalnya. Perbedaan ini bukan hanya dilatarbelakangi oleh jenis, bentuk, material, serta fungsi dari perabotan tersebut, tetapi yang paling mendasar adalah orientasi poenciptaannya yang berkaitan dengan kualitas teknik dan ekspresi yang terkandung dalam proses tersebut. Dalam membuat cobek, keren, dandang, akan sangat berbeda dengan membuat sangku, wanci, dan sebagainya. Demikian juga dalam pembuatan seni primitif Asmat misalnya, walaupun menggunakan peralatan sederhana bukan berarti teknik sangat dominan, namun karena orientasi pembuatan tersebut sebagai simbol-simbol rohroh nenek moyang, maka pembuatannya sangat ekspresif. Di samping itu dengan kesederhaan alat, namun niat dan kemauannya sangat tinggi, maka akan lahirlah karya yang sangat ekspresif.

Imaji, Vol.4, No.1, Februari $2006: 32$ - 45
Didasari oleh rasa estetis yang sangat tinggi pada setiap manusia dan rasa bakti yang tulus iklas terhadap Yang Maha Kuasa, mereka akan selalu membuat yang terbaik dan yang terindah pada perabotan yang akan dipergunakan untuk kepentingan upacara. Pembuatan Periuk untuk tempat ari suci akan sangat berbeda dengan periuk untuk memasak. Kemampuan membuat ornamen dalam usaha untuk menambah keindahan sebuah perabotan adalah merupakan muntahan ekspresi dari seseorang untuk menciptakan sesuatu yang indah dan menarik.

Peninggalan bersejarah dari Agama Hindu dan Budha yang berupa candicandi dan yang lainnya merupakan bukti autentik yang sangat kuat dalam bidang seni rupa di mana segala sesuatunya diciptakan dengan penuh nilai estetis disertai dengan nilai filosofis. Karya monumental yang adiluhung dengan nilai estetis yang tinggi tentunya sangat sulit memberikan batasan kualitas teknik dan ekspresi dalam proses penciptaan tersebut. Dalam hal ini antara teknik dak ekspresi mempunyai kekuatan yang sama, di samping memerlukan ketekunan juga memerlukan kosentrasi yang tinggi dalam proses tersebut. Karya yang unik bukan berarti hanya memerlukan ketrampilan belaka dan ekspresi terpinggirkan, tetapi teknik dan ekspresi akan muncul bersamaan dan tertuang bersamaan pula dalam proses tersebut.

Pemusatan perhatian yang sangat mendalam dalam sebuah proses penciptaan di mana rasa dan jiwa merasuk luluh, lebur pada sebuah karya yang bermuara pada produk yang dihasilkan dengan pancaran karakter yang tersirat dalam karya tersebut, itu merupakan curahan ekspresi seseorang dalam menciptakan karya seni. Seorang sangging di Bali yang membuat Barong untuk sesuhunan proses penciptaannya sangat berbeda dengan seorang kriyawan yang membuat barong untuk hiasan atau untuk pertunjukan seni pariwisata. Demikian juga seorang Empu pembuat keris proses penciptaannya sangat berbeda dengan Pandhe pembuat golok. Walaupun dengan teknik dan ketrampilan yang sama namun totalitas rasa dan jiwa dan orientasinya sangat jauh berbeda. Pancaran karakter tersebut merupakan curahan ekspresi seorang sangging atau empu dalam menciptakannya sehingga karya tersebut sangat bertaksu.

Sebagai sebuah karya budaya, stratifikasi sosial juga akan menempatkan teknik dan ekspresi produk kriya pada wilayah yang berbeda. Seni kriya masuk dalam jajaran kebudayaan rakyat (folk-culture) dan seni kriya yang masuk pada wilayah budaya adiluhung High- culture). Seni kriya di masyarakat adalah seni kriya yang bersahaja tidak complicated, namun spontan dan jujur. Seni rakyat adalah seninya komunitas pedesaan yang masih akrab yang hemogen dan berfungsi untuk mengikat solidaritas komunitas. Seni kriya istana adalah seni yang penuh makna dan nilai filosofis yang tinggi (Soedarso, 2002:1).

Dicermati dari proses penciptaan dan orientasi serta hasil yang diciptakan,

Komparatif Teknik dan Ekspresi Dalam Seni Kriya (I Wayan Suardana) 
bahwa dalam seni kriya adiluhung antara teknik dan ekspresi mempunyai kekuatan yang hampir sama. Walaupun produk kriya tersebut dihasilkan dengan penuh ketekunan, karena tuntutan sebuah makna maka ekspresi juga tercurah secara totalitas. Dalam produk kriya yang ada di masyarakat dimana kekuatan teknik disana sangat dominan dalam artian walaupun hasilnya begitu spontan dan jujur, karena orientasinya adalah pada nilai praktis dan untuk kebutuhan hidup seharihari, maka dalam proses penciptaannya katrampilan menjadi lebih dominan.

\section{E. Teknik dan Ekspresi dalam Kriya Akademik}

Untuk membahas wilayah teknik dan ekspresi dalam jaman modern atau post modern sebaiknya kita membahas hal tersebut pada perjalanan kriya yang ada di akademik. Untuk mengetahui secara mendalam perjalanan kriya akademik kita tidak bisa lepas dari perjalanan jurusan kriya yang berada di lembaga tinggi sen rupa di Institut Seni Indonesia Yogyakarta, yang dalam kurun waktu setengah abad predikat jurusan kriya selalu berubah sesuai dengan perkembangan ilmu dan teknologi. Dari perjalanan ini secara tidak langsung persoalan teknik dan ekspresi dalam kriya akan muncul dengan sendirinya.

Berdirinya Akademi Seni Rupa Indonesia (ASRI) tahun 1950, salah satu jurusan yang yang menjadi cikal bakal jurusan kriya adalah bagian "sen pertukangan". Dimasukannya kriya sebagai seni pertukangan ini karena orientas pendidikan waktu itu adalah menjadikan orang terampil dalam mengerjakan seniseni tradisional yang bersifat ornamentik dengan menekuni beberapa motif dan gaya yang telah ada seperti motif Jepara, Motif Majapahit, Motif Pajajaran atau mengukir logam dengan teknik dan gaya yang itu-itu saja (Soehadji, 2000:2) Penekanannya adalah di samping memahami seni-seni tradisional yang ada, juga ketekunan dan kemampuan ketrampilan menjadi sasaran paling utama sehingga lulusan yang dihasilkan betul-betul mempunyai penguasan teknik yang tak dapa diragukan. Kemampuan teknik menjadi suatu yang sangat berharga dan menjadi barometer keberasilan seorang siswa.

Menjadi bagian jurusan yang terisolir di ASRI bertahun-tahun karena dianggap sebagai jurusan yang kurang kreatif, yang hanya mempelajari seni-sen yang telah ada dan sebagai pengisi ornamentik belaka, maka usaha kemandirian terus dilakukan. Pada tahun 1963 "seni pertukangan" berubah menjadi jurusan "Seni Kerajinan". Wilayah seni kerajinan semakin melebar tidak sebatas pada sen ornamentik belaka, tetapi sudah meluas pada wilayah produk lainnya seperti pembuatan meja, kursi, almari, atau perabotan rumah tangga lainnya. Walaupun wilayah jelajah sudah meluas, tetapi penekanannya masih tetap pada kemampuan teknik dan ketrampilan tangan. Untuk menciptakan suatu barang yang praktis dan estetis diperlukan ketrampilan yang tinggi baik dalam proses pembentukan, menghias maupun finishing. Tangan-tangan trampil dalam bidangnya sepert

Imaji, Vol.4, No.1, Februari $2006: 32$ - 45 mengukir, membatik, menganyam, membuat keramik dan sebagainya menjadi sasaran utama dalam proses pendidikan.

Peningkatan status "ASRI" menjadi Sekolah Tinggi Seni Indonesia "ASRI" pada tahun 1969, jurusan seni kerajinan berubah menjadi jurusan Seni Kriya. Dengan seni kriya wilayah garapan dan produk lebih meluas dengan menciptakan berbagai produk yang tidak hanya fungsional, namun juga yang non fungsional. Orientasi penciptaan tidak hanya mementingkan ketrampilan, tetapi curahan ekspresi juga terkandung di dalamnya. Seni kriya adalah suatu cabang seni yang memerlukan kekriyaan atau crafsmanship yang tinggi. Tidak pula berarti bahwa ia tidak memerlukan kreasi dan ekspresi, tetapi karena derajat kekriyaan yang diperlukan begitu tinggi dan rumitnya, maka ekspresi agak terdorong jauh kebelakang (Soedarso, 2002:15).

Berkaitan dengan perkembangan jaman dan tuntutan berkreasi dalam sebuah karya seni, banyak cabang seni kriya mengalami perubahan fungsi. Kerajinan keramik yang awalnya hanya mengerjakan perabotan yang fungsional, karena tuntutan kebutuhan yang lain yaitu sebagai media ekspresi, banyak lahir keramik murni. Bentuk-bentuk binatang yang awalnya difungsikan sebagai celengan bentuknya lebih dikembangkan dan dibuat lebih artistik dan jadilah bentuk binatang yang berfungsi sebagai hiasan. Demikian juga dalam seni batik yang awalnya lebih banyak mengerjakan batik untuk kebutuhan sehari hari seperti jarik, kemben, destar dan sebagainya, kemudian berkembang dimana teknik batik dijadikan ekspresi dalam penciptaan seni lukis. Maka lahirlah seni lukis batik yang penuh ekspresi.

Sebagai usaha untuk mensejajarkan diri dengan seni murni lainnya, maka seni kriya mengubah wujudnya menjadi Kriya seni. Istilah "seni" yang ada dibelakang kriya disini adalah merupakan suatu penekanan bahwa kriya merupakan suatu karya dari curahan ekspresi yang dalam dari penciptanya. Kriya merupakan salah satu media dalam mencurahkan ekspresi bagi seorang seniman. Kriya tidak hanya berkutat pada kekriyaan saja, namun ide, gagasan, dan ekspresi juga ada dalam seni kriya. Yang seni adalah yang ekspresif dan kriyapun adalah karya yang ekspresif.

Merebaknya wacana yang seni adalah yang ekspresif dan dikatakan hanya terdapat pada seni murni, maka seni kriya yang ekpresif memproklamirkan sebagai kriya seni yaitu sebuah hasil karya yang ekspresi dengan media kriya. Akhirnya istilah "Kriya Seni" dikuatkan dalam rapat konsorsium seni yang bertujuan untuk mewadahi karya-karya kriya dengan nilai artistik yang tinggi dan dipakai untuk membedakan dengan kriya dalam arti "Kerajinan" dan "Disain Kriya" yang akan dimassaproduksikan. Sebagaimana kondisi kriya dan seni di awal mula, kriya seni berbatasan dengan seni murni hanya dengan tapal batas yang 
sangat minim yaitu hanya aksentuasi pembuatannya, tekanannya pada ekspresi dan crafsmanship yang tinggi yang nota bena keduanya mesti ada dalam setiap karya seni. Yang kuat ekspresinya adalah seni murni dan yang crafsmanshipnya kuat adalah kriya seni (Soedarso, 1999:36).

Perlu disadari bahwa kelahiran kriya seni merupakan tuntutan kreativitas individu yang bergerak maju untuk menunjukan pada dunia seni bahwa telah lahir kriya yang lain yaitu kriya seni. Seniman kriya tentunya mempunyai hak yang sama dalam menyalurkan kreasinya dalam rangka tanggung jawab pribadi atau individu, khususnya dalam hal pengkayaan gaya dan ragam kriya sesuai dengan konstelasi jaman sebagai warisan bagi generasi berikutnya. Sejalan dengan tuntutan tersebut terjadi juga gejolak seakan bergeliat dan meloncat dengan melahirkan kriya seni atau kriya konterporer. Suatu gejolak yang tak mungkin ditolak dan metinya diakuai, karena setiap jaman yang ditangkap akan melahirkan teks yang sesuai dengan konteks yaitu konstelasi jaman (Sunarya, 2003:203).

Sepertinya tidak salah dalam era modern dan post modern dewasa ini para seniman kriya bergeliat, bergejolak dan bergerak membuka kreatifitas menembus cakrawala seni dengan menciptakan karya-karya yang spektakuler dan monumental sebagai refleksi jaman tentunya dengan mewujudkan sebuah karya yang universal dimana segala asfek-asfek estetika tersirat dan terpancar dengan porsi dan kekuatan yang sama. Kemunculan karya ini akan menjadi sebuah tonggak dimana kriya telah melahirkan sebuah karya yang monumental yang patut diakui dan dihargai sebagai sebuah karya seni yang adiluhung.

Tampilnya berbagai bentuk dan warna seni rupa di jagat raya ini yang dibarengi dengan merebaknya wacana yang mengiringinya menjadikan sulit dan tipisnya batas wilayah antara seni yang satu dengan yang lainnya. Lintas wilayah antara seni yang satu dengan seni yang lainnya sudah menjadi suatu hal yang wajar dan itu merupakan suatu pertanda terbukanya wilayah kreativitas dan tidak terbelenggu oleh pakem atau norma yang ada pada wilayah seni itu sendiri. Dalam hal ini tentunya tidaklah wajar kalau mendiskriditkan wilayah seni dengan memberikan tilang pada seni yang melewati batas wilayahnya. Apalagi selalu menjadikan obyek penderita pada cabang seni yang ada. Demikian juga halnya dengan kelahiran kriya seni disini merupakan pengukuhan seni kriya sebagai cabang seni rupa sebagaimana halnya dengan cabang seni rupa lainnya merupakan sebuah karya seni sebagai proses kreratif dan ungkapan ekspresi estetik dalam bentuk yang khas (Rohidi, 2002:7). Curahan ekspresi estetik yang dalam terkadang bergerak tanpa batas yang pada akhirnya melintasi batas wilayah sendiri, dan dengan gerang sering mendapat tegoran yang sinis, sementara seni lain dengan seenaknya mencaplok wilayah kriya dan dengan sombongnya tetap menproklamirkan ini adalah karya yang ekspresif murni.

Imaji, Vol.4, No.1, Februari $2006: 32$ - 45

\section{F. Teknologi dan Ekspresi}

Teknologi selalu mengiringi dan merupakan sarana dalam teknik penciptaan. Teknologi selalu menjadi tulang punggung dalam kelahiran seni kerajinan maupun kriya seni, dalam artian dengan bantuan teknologi maka seni tersebut akan lahir, tentunya disesuaikan dengan perkembangan jaman yang selalu mengikutinya. Dengan menggunakan teknologi bukan berarti nilai seni atau ekspresi dalam karya tidak ada, tetapi penyelesaian dengan menggunakan tangan dan curahan jiwa adalah merupakan karya seni. Disini teknologi hanya sebagai pembantu untuk mempermudah proses penciptaan dan itu sangat diperlukan.

Timbul kekhawatiran bahwa teknologi akan mematikan ekspresi, karena semuanya dapat dikerjakan dengan mesin-mesin. Kenyataannya tidak demikian ternyata dengan adanya teknologi ruang berekspresi menjadi lebih luas. Banyak muncul mesin-mesin yang membantu untuk berekspresi, demikian juga banyak bahan-bahan sintetik yang dapat digunakan sebagai media berekspresi. Dengan demikian sebaiknya kita berakrab-akrab dengan teknologi, dengan memanfaatkannya sebaik mungkin sehingga kita tidak akan ketinggalan jaman. Jadikanlah teknilogi sebagai sarana untuk berekspresi, karena teknologi akan banyak memberikan kemudahan dalam kita mencurahkan ekspresi.

\section{G. Penutup}

Teknik dan ekspresi adalah dua aspek yang harus hadir dalam sebuah karya seni walaupun kualitas dan aksentuasi kemunculannya yang berbeda. Tanpa adanya dua aspek ini niscaya karya seni itu muncul. Teknis lebih berkaitan dengan proses kerja sedangkan ekspresi adalah orientasi dan sentuhan rasa yang menyertainya.

Garis lintang antara teknik dan ekspresi dalam kriya sebenarnya sudah kentara dengan jelas pada perbedaan wilayah antara seni kriya dan seni kerajinan. Kualitas dan aksentuasi teknik dan ekspresi dari dua seni ini sangat berbeda yang berimplikasi pada proses penciptaan dan produk yang dihasilkan. Kekuatan teknik sangat dominan pada seni kerajinan sedangkan dalam kriya seni teknik dan ekspresi mempunyai kekuatan yang sama. Perlu ditekankan disini bahwa dalam seni kerajinan walaupun sifatnya produksi, apabila dikerjakan oleh manusia yang mempunyai jiwa dan rasa, ekspresi tetap tercermin dilamnya. Hal ini dapat dilihat walaupun bentuk dan jenisnya sama namun hasilnya pasti akan berbeda, dan perbedaan ini adalah curahan ekspresi yang ada di dalamnya.

Kriya seni adalah sebuah usaha untuk menjawab dan menunjukan pada dunia seni bahwa kriya merupakan suatu wahana seni rupa yang sarat ide, gagasan, kreasi, dan ekspresi dalam proses penciptaannya. Kriya seni merupakan sebuah media yang sangat representatif untuk berkreasi dengan mencurahkan segala ekspresi dalam menciptakan sebuah karya seni. Teknik merupakan sarana yang 
sangat diperlukan dalam proses ini, karena tanpa teknik, ekspresi emosional yang meluap-luap tidak akan melahirkan sebuah karya seni.

Teknologi merupakan sarana untuk berekspresi, oleh sebab itu kita harus dapat memanfaatkannya secara tepat sehingga apa yang akan diciptakan dapa berasil dengan cepat dan maksimal. Teknologi bukan musuh seorang seniman, melainkan sesuatu yang harus diakrabi.Teknologi berperan sangat dominan baik yang berkaitan dengan peralatan maupun sistem imfomasi. Oleh sebab itu kita harus masuk dalam wilayah teknologi, kalau tidak demikian kita akan tertingga jauh dengan negara-negara lain baik dalam proses penciptaan maupun sistem imformasi yang ada.

Sebagai catatan yang perlu diwaspadai adalah dimanfaatkannya ekspresi sebagai kedok atau topeng untuk menutupi ketidakmampuannya dalam teknik, dengan mengeluarkan berbagai wacana sebagai sebuah konsep dalam berkarya Bagaimanapun juga sebagai seorang kriyawan kemampuan teknik adalah dasa elementer yang harus dikuasai. Sungguh sangat memalukan apabila kita selalu bersembunyi dibelakang konsep atau ekspresi lantaran kita kurang menguasai teknik sebagai proses kerja.

\section{DAFTAR PUSTAKA}

Djatiprambudi, Djuli. 2004 "Upaya Mengebor Sukma". Makalah, Puri Art Gallery, Malang.

Guntur. 2001. Teba Kriya. Surakarta: Artha-28.

Gustami SP. 2003. "Proses Penciptaan Seni Kriya: Untaian Metodelogis". Makalah Yogyakarta: Program Pascasarjana ISI.

. 2002. "Memantapkan Wacana Seni Kriya Indonesia Sebagai Akar Seni Rupa Indonesia”. Makalah Yogyakarta: Program Pascasarjana ISI. 1991. "Seni Kriya Indonesia Dilema Pembinaan Dan Pengembangannya". Makalah Yogyakarta: Program Pascasarjana ISI.

Irianto, Asmujo Jono. 2005. "Kriya dalam Perdebatan Wacana Konterporer", Visual Art, Edisi Pebruari/Maret, 2005.

Munro, Thomas. 1969. The Art and Their Interrelations, Cleveland and London: The Press of Case Western Reserve University.

Read, Herbert. 2000. Seni: Arti Dan Problematiknya. Terj. Soedarso. Yogyakarta: Duta Wacana University Press.

Rohidi, Tjetjep Rohendi. 2002. "Mempersiapkan dan Mengarahkan Seni Kriya Indonesia dalam Era Globalisasi yang Terbuka". Makalah Yogyakarta: Program Pascasarjana ISI.

Soedarso Sp. 1990. Tinjauan Seni: Sebuah Pengantar Apresiasi Seni. Yogyakarta: Saku Dayar Sana.
. 2003. "Seni Sebagai Komunikasi dan Ekspresi Emosi”. Makalah Yogyakarta: Program Pascasarjana ISI.

. 2002. "Merevitalisasi Seni Kriya Tradisi Menuju Aspirasi Dan Kebutuhan Masyarakat Masa Kini”. Makalah Yogyakarta: Program Pascasarjana ISI.

. 1999. "Seni Kriya: Cabang Seni Yang Sedang Gelisah", Seni VII/01, BP. ISI.Yogyakarta.

Soehadji, M. 2000. "Kriya Seni Kreasi ISI Yogyakarta". Makalah Galleri Nasional Jakarta.

Sunarya, I Ketut. 2003. “Garis Lintang Penampang Kriya (Seni Refleksi Jaman Yang Ambigu)". Majalah Imaji Vol. 1, No.2, FBS UNY

Stolnitz, Jeremo. 1960. Aestetics And Philosophy Of Art Criticim: A Critical Introduktion, Boston: Houghton Mifflin Company. 